\title{
Problems of Formation of Ecological Networks for Environmental Safety of Odesa Region
}

\author{
Victoria Yavorska ${ }^{1 *}$, Kateryna Kolomiyets ${ }^{1}$, Valentina Trigub ${ }^{1}$, Ihor Hevko ${ }^{2}$, and Olexandra Chubrei $^{3}$ \\ ${ }^{1}$ Odesa I .I. Mechnykov National University, Champaign lane, 2, Odesa, 65058, Ukraine \\ ${ }^{2}$ Ternopil Volodymyr Hnatiuk National Pedagogical University, M. Kryvoniis st., 2, Ternopil, 46027, Ukraine \\ ${ }^{3}$ Yuriy Fedkovych Chernivtsi National University, M.Kotsiubynskyi st., 2, Chernivtsi, 58012, Ukraine
}

\begin{abstract}
Currently, the concept of sustainable development of nature and society is gaining relevance, a key aspect of which is the development of the ecological network. In Ukraine, there is a regulatory framework for the formation of an ecological network of three levels - Pan-European, National and regional. One of the important problems is that in the developed schemes of regional eco-networks should be interconnected to the eco-networks of neighboring regions and countries. The main features of the ecological network of the Odesa region are due to its coastal position and location mainly in the Steppe, partly Forest-Steppe landscape zones. The region includes vast areas of coastal territories and coastal waters - coastal zones, which concentrate unique protected areas. Mandatory basis for the formation of ecological networks is land use. The proposed concept of geoplanning is based on planning developments of the main components of the territory: the natural environment; population; economic activity. The basic characteristics of the natural environment are the landscape map and physical and geographical zoning of the territory. Maps of resilience of the natural environment to man-caused load, natural and ecological potential of the territory, levels of ecological and economic balance have already been drawn up. This series of maps for the needs of planning the territory of Ukraine should be continued by project maps of national and regional ecological networks, as well as maps of ecological capacity of the territory for population settlement, various economic activities and the general level of economic development in general. For the needs of spatial planning it is necessary to emphasize the levels of anthropogenic and urban pressures on the natural environment in the settlement of the population. Allocation of water fund lands in kind and strict regulation of their use is the main prerequisite for the formation of ecological networks of Ukraine and its regions.
\end{abstract}

\section{Introduction}

Ukrainian geographers took the experience from European countries regarding territory planning. Formational problems of ecological networks for environmental safety, ecological networks in country and regions are mentioned as the most ferocious and demanded in Ukraine. The current Ukrainian legislation provides general legal foundations for the formation of ecological network of environmental safety in the country and its regions. Primarily the Law of Ukraine: "On the national Program for Creating the National Ecological Network of Ukraine for the years 2000-2015" (1989-III, from 21.09.2000) also "Ecological Network of Ukraine" (1864-IV, from 24.06.2004). The Cabinet of Ministers of Ukraine resolution in year 2000 obliged Council of Ministers of ARC and regional state administrations to develop concepts and programs of regional ecological networks as the components of national environmental networks. Further development of schemes for territorial planning began regionally. Our study overlooks the problems of national and regional territorial planning and environmental activity in Ukraine.

The development and realization of national environmental strategy occurs in the context of transition of our country to the model of sustainable development according to decisions of UN Conference on environment and development (3-14 June 1992 Rio de Janeiro), Johannesburg Summit (2002) and political guidance of Pan-European process "The environment for Europe" require the greening of public consciousness, the introduction of a system of professional environmental training, raising the level of environmental education and culture, in general, the implementation of a balanced state ecological policy.

The law provides for the creation of a framework of ecological security of the country as a single system of territories subject to special protection, which are composed of lands of nature reserves, health and recreational purposes, historical and cultural purposes, as well as lands of forest and water fund, areas of natural vegetation agricultural, residential and public buildings and other purposes. The law defines the formation of national and regional ecological networks as one of the

$\overline{{ }^{*} \text { Corresponding author: yavorskaya } @ \text {,onu.edu.ua }}$ 
most important prerequisites for sustainable socioeconomic development of the country.

Ecological network (eco-network) is a single territorial structure of protected and undisturbed areas, which ensure the preservation of landscape and biological diversity, create preconditions for rational use of nature and ecological improvement of the territory. The constituent elements of ecological networks are natural regions, natural corridors and buffer zones. At present, only natural regions - territories and objects of the nature reserve fund - have been identified in the area to some extent. Natural corridors and buffer zones are still waiting to be substantiated and designed.

Legislation in Ukraine clearly defines the possible spatial resources for the development of the ecological network. It is important that the inclusion of territories in the eco-network does not change the form of ownership and category of land. In addition, the owners and users of these areas can receive budget funding for wildlife conservation. The basis of the ecological network is, of course, protected areas, but in fact all areas where natural landscapes have been preserved to some extent can become elements of the ecological network. The natural ecological framework in the form of ecological networks should approximately cover a quarter of a third of the country's territory.

\section{Results and discussion}

The territory of the Odessa region is located mainly in the steppe, partly - forest-steppe natural zones. This determines its high agricultural production potential and rich recreational resources. This situation, however, determines the negative features of the nature of the region, in particular its low water and the region's small forest cover. This is especially felt in the coastal areas where a significant part of the nature reserve fund is concentrated, covering unique natural complexes and ecosystems of floodplains, estuaries, lakes, sea coasts, spit, sea shelf, which should be considered as a unique and invaluable regional and national resource. Its use requires strict regulation and regulation.

The coastal position of the region determines the most common problems of regional nature management. The territory is crossed by the rivers Danube, Dniester, Southern Bug, Dnieper, which remove pollutants from large water intakes and accumulate them in places of maximum concentration of population and economic activity. The contact zone land with sea, as well as the junction of river and estuarine waters with marine waters plays an important role in the regional and global biosphere barrier. It is in this strip that the most valuable objects of the country's nature reserve fund are located.

The lack of the most scarce water resources in the coastal strip is due to the distribution, primarily of surface runoff. The transit nature of rivers and the redistribution of water resources through main canals increase the potential of water resources, but do not radically solve the water problem in the region.

There is an acute shortage of forest stands, especially in the coastal areas of large cities and in recreational areas. High-value recreational resources of the region, especially the sea coasts, are limited in the use of significant pollution of sea and estuarine waters, their insufficiently clearly regulated economic operation. World experience shows that sea and estuarine coasts should be considered as a unique and valuable regional and national resource. Its use requires strict regulation and regulation.

The concentration of population, infrastructure, and economy in the coastal zone of Odessa region exceeds its level in the deep land part, which determines the characteristic type of territorial organization of the economy - coastal facade, the main economic axis of which is the coastline, estuaries and below large rivers along which are the main economic centres. The latter are represented by powerful port-industrial complexes, industrial hubs, resorts. At the same time, there is a high unevenness in the settlement of the population and the location of the economy. The $50-70 \%$ of the region's inhabitants, $80 \%$ of its industrial potential, most of the transport infrastructure, almost all recreational facilities are concentrated in the coastal strip.

The law provides for the creation of a framework of ecological security of the country as a single system of territories subject to special protection, which are composed of lands of nature reserves, health and recreational purposes, historical and cultural purposes, as well as lands of forest and water fund, areas of natural vegetation agricultural, residential and public buildings and other purposes. The law defines the formation of national and regional ecological networks as one of the most important prerequisites for sustainable socioeconomic development of the country.

Ecological network (eco-network) is a single territorial structure of protected and undisturbed areas, which ensure the preservation of landscape and biological diversity, create preconditions for rational use of nature and ecological improvement of the territory. The constituent elements of ecological networks are natural regions, natural corridors and buffer zones. At present, only natural regions - territories and objects of the nature reserve fund - have been identified in the area to some extent. Natural corridors and buffer zones are still waiting to be substantiated and designed.

The main feature of the formation of the ecological network of the Ukrainian Black Sea region is that it is a part of the Pan-European (Eastern European) Ecological Network, as well as the national ecological network, and must be agreed with them $[1,2]$.

The regional ecological network, which forms the natural framework of ecological safety of Odesa region, includes elements of ecological networks of different levels: international - Pan-European ecological network; national - National Ecological Network of Ukraine; regional and local. Elements of the Pan-European Ecological Network are the natural region of the Lower Danube and two ecological corridors - Prut (Lower Danube-Carpathians) and Azov-Black Sea, which covers the coastal-maritime territorial and aquatic natural complexes of the Black Sea coast, and the Danube (Lower Danube valley) [3-5]. 
Ukraine takes part in international cooperation on the formation, conservation and use of the Pan-European Eenvironmental Network and the creation of its transboundary elements. Existing international agreements on the formation, preservation and use of the ecological network, approved by the Supreme Council of Ukraine, are part of the national legislation of Ukraine.

It is envisaged to ensure the connection of the regional ecological network of Odesa region with the ecological networks of neighboring regions within the framework of the unified national ecological network of Ukraine, as well as with certain elements of the PanEuropean ecological network. These include the Danube Biosphere Reserve, the Lower Prut Biosphere Reserve of Moldova and the joint Lower Dniester National Nature Park with Moldova, as well as international natural corridors running through the Danube and Dniester valleys.

The decision of the Odesa Regional Council of 20.05.2011 № 136-IV approved the Regional scheme of formation of the ecological network of Odesa region, which was developed by the Southern Research Center of the National Academy of Sciences of Ukraine and the Ministry of Education and Science of Ukraine under the scientific guidance of Odesa I .I. Mechnykov National University in the framework of research work "Development of a regional scheme for the formation of an ecological network." Despite the fact that the task of forming ecological networks at the regional level as a whole can be solved, the most difficult remains the development on a large geographical scale of the composition and boundaries of ecological (natural) corridors.

The regional eco-network has cross-border elements and should be connected with the eco-networks of Moldova and Romania, Vinnytsia, Kirovohrad and Mykolayiv regions of Ukraine.

Transboundary elements of the regional ecological network of Odesa region: With Vinnytsia and Kirovohrad regions Odesaregion borders along the Galicia-Slobozhansky forest-steppe natural corridor, and with Mykolayiv - by Tiligul estuary, which in its lower part already has the status of regional natural parks.

Natural corridors that are part of the regional ecological network of Odesa (Lower Danube, Black Sea coastal, Khadzhyderskyi, Sasyk-Kohylnytskyi, KyrhyzhKytaiskyi, Yalpuzkyi; national - Azov-Black Sea, Coastal-Dniester) gravitate to the coastal zones [6].

The core of the regional eco-network is the coastal strip, which we consider as a unique territorial-aqual natural system and which is designated as the AzovBlack Sea Ecological Corridor of the European Econetwork, where biosphere and nature reserves and national nature parks of Ukraine are concentrated. At the same time, the natural complexes of the coastal strip are very vulnerable to anthropogenic and man-caused loads: the mouths of the river collect pollution from huge watersheds every year; sea shores have complex and various geogdynamics (abrasion, landslides, siltation and accumulation of sediments, etc.); shallow shelf water has a small "environmental capacity" and low capacity for self-cleaning. In coastal areas, there is and is constantly growing socio-ecological contradiction between their extremely high attractiveness for settlement and many economic activities, on the one hand, and extremely high environmental vulnerability of sea coasts and adjacent waters - on the other.

World practice considers coastal strips (coastal zones) as a unique and valuable resource of regional, national and global importance, which requires a special legislative and regulatory framework for its use. In many countries it has been operating for a long time a special legal framework for nature usage and integrated management in coastal zones [7]. Ukraine has approved the Concept of Environmental Policy of Ukraine for the period up to 2020 (Decree of the Cabinet of Ministers of Ukraine of October 17, 2007 № 880-r), which emphasizes the problems of environmental protection of sea coasts and shelf strips.

Experience in the formation of ecological networks shows that for the formation of regional ecological networks it is necessary to review land use in the region, as well as to move at the regional and local levels to the agro-landscape organization of rural areas. The agrolandscape organization should take into account as much as possible the natural and geographical features of the territory during its agricultural use, in particular the cutting of land uses, massifs and fields of arable lands with their coordinated reference to the natural basis, to landscape areas and tracts. Note that in the context of radical agrarian and land reforms currently underway in Ukraine, there is a significant fragmentation of land tenure and land use, there is a significant departure from the large-scale organization of the territory and cutting large fields, which creates the necessary conditions for agro-landscape organization. This problem is especially relevant for forest-steppe and steppe landscape zones, in which the Odessa region is located.

The basis of the regional ecological network should be a nature reserve fund, also the share of regional ecological network should be increased at the expense of recreational areas and degraded and unproductive agricultural lands, which occupy large areas and require their return to the category of natural lands.

Degraded and unproductive agricultural lands are a significant reserve of land for the creation of ecological networks. Ukraine is a world record holder in terms of the level of plowing and agricultural development of the territory, and this is a sad and unnecessary record. Since 1995 to 1997, the State Land Cadastre was introduced in Ukraine, in the presence of which it became possible to actually withdraw from cultivation of unproductive and degraded agricultural land, preserve it and gradually return it to the state of natural lands. In most regions, at least $10-15 \%$ of agricultural land needs such a transformation.

Territories and objects of the nature reserve fund of the region form the basis of the regional ecological network of Odesa region and form most of its nodal elements. The development of the nature reserve fund of Odesa region is carried out in accordance with the regional Program of formation of the national environmental network in Odesa region, which envisages increasing the share of the nature reserve fund 
of the region to $5 \%$. The latter component includes a list of protected areas that were reserved by the decision of the Odesa Regional Council of October 1, 1993 №496XXI "On measures to preserve and develop the nature reserve fund of the region." Currently, the nature reserve fund of the region includes 125 territories and objects with a total area of 163523.05 hectares, of which 18 are of national importance and 107 local [8].

Territorial analysis of the structural elements of the ecological network of the Odessa region showed that the share of territories suitable for the formation of the ecological network is $30.5 \%$ of the area of the region. At the same time, there is a heterogeneity of this indicator in the administrative-territorial units of the region. The location of nature reserves in the region is uneven. In Lyubashivsky, Krasnooknyansky and Saratsky districts they are completely absent, and in other administrative units of the region their number is from the 1 st to the 8 th. Lands of the nature reserve fund occupy $4.9 \%$ of the territory of the Odessa region, this figure can be increased to $7-10 \%$ due to the expansion of existing NPF facilities and the creation of new nature protection areas.

The distribution between users and owners of land plots of territories and objects of the nature reserve fund is as follows: $43 \%$ of protected areas are used by forestry enterprises, $35 \%$ are communally owned by city and village councils, the rest are used by objects of the Ministry of Education and Science Ukraine, the Ministry of Health of Ukraine, the National Academy of Sciences of Ukraine, individual organizations of collective ownership.

The ecological network is defined as a natural framework of ecological safety of the territory and is considered as an obligatory component of planning of the territory. For the needs of planning of the regions territory we have developed the Concept of Geoplanning (Fig.1).

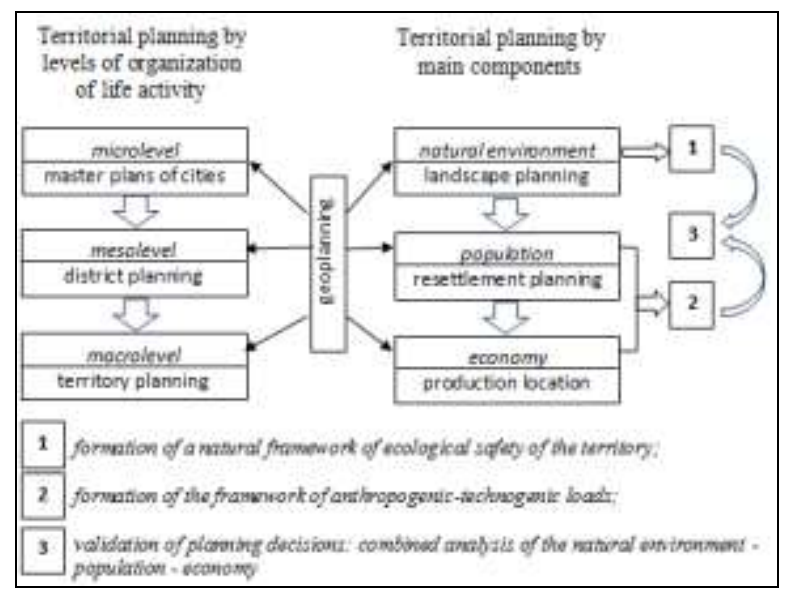

Fig.1. Conceptual scheme of "geoplanning" [12]

It is based on planning developments of the main components of the territory: the natural environment; population; economic activity. Let's consider the methodological principles of the General scheme of planning of the territory of Ukraine on its main components - the environment, population and economy [9]. The basic characteristic of the natural environment is the landscape map and physical and geographical zoning of the territory. Schemes of agroclimatic, agrosoil and many other component zonings are widely used. Recently, dozens of applied natural resource and natural ecological maps of Ukraine have been developed. Maps of resistance of the natural environment to technogenic loading, natural and ecological potential of the territory, levels of ecological and economic balance of the territory are already made (V.A. Baranovsky \& P.G. Shishchenko, 2005). Such a series of maps for the planning of the territory of Ukraine needs to be extended by project maps of national and regional ecological networks. And also maps of the ecological capacity of the territory to the resettlement of the population, maps of the different types of economic activity $[10,11]$. Note that a sketch map of the national ecological network has already been developed [9].

Perhaps the most developed area of modern geography is the territorial organization of the population. With the help of thematic series of maps in the scientific and primary atlases, the composition and structure of the population, their dynamics, and population settlement are shown. For the needs of the planning of the territory, it is necessary to accentuate the loading levels of the anthropogenic and urban areas on the natural environment and to typify the territories according to the general nature of settlement and peculiarities of residential land use.

Geographers have to avoid of the strict linkage of the settlement systems to the administrative-territorial subdivision. First, settlement systems are historically and genetically more ingrained than any scheme of administrative-territorial organization. Secondly, a new administrative reform is underway in Ukraine. The new administrative-territorial subdivision has been solidified by explicit systems of settlement, and not by "squeezing" the settlement into new administrative units. Third, an in-depth analysis of the historical and geographical genesis of population settlement and its geospatial differences will make it possible to regionalize Ukraine fairly objectively and thus fulfill one of the prerequisites for its European integration.

A difficult methodological issue is the typification of populated areas for geoplanning purposes. In the General scheme of planning of the territory of Ukraine [9] the zone of urbanization which is divided on levels of industrial and town-planning development into three types is allocated: 1) critical; 2) high; 3) average. Typification of areas by the nature of settlement and development should be continued. Urbanized areas are the territories of individual cities and urban agglomerations, they are large cities with suburban areas, and they are urbanized areas of country houses and cottages (which do not have their own administrative status). Additionally, urbanized zones and areas can be differentiated by building density, population density, and infrastructure. Territories with rural settlement differ in genetic types of settlement, in population and density of settlements, in the density of the rural population.

The most complicated and least developed is the analysis of the territorial organization of economic activity. It is, in particular, about the systematics of types of economic use of territories - industrial, agricultural, 
forestry, transport, maritime, recreational, and environmental. Geographers traditionally develop maps of agricultural specialization. The General scheme shows eight functional types of agricultural use of the territory and one - forestry. But such a system for the needs of spatial planning should be further detailed. In particular, it is necessary to show different levels of intensity of agricultural use in the structure of land and land use, the complexity of existing production, etc.

The antithesis of the framework of ecological safety is the framework of anthropogenic and man-made loads, which integratedly represents the geospatial (territorial) distribution of environmental impacts of all socioeconomic components - population, artificial material world created by man, economic and spiritual activities. Its structural elements are settlements, transport communications, lands of various economic purposes and uses, as well as socio-economic objects that pose an ecological danger. To date, as a rule, all of the above components are considered separately.

According to the concept of the anthropogenic and man-made loads framework, its target guidelines are "determining the nature of the territorial elements of the anthropogenic and man-made loads framework and identifying their regular spatial connections in order to identify ways to optimize land use in the regions and improve the overall structure of land use; systematization and typification of anthropogenic and man-made loads framework elements, optimization of the area, structure, condition of the frame elements in order to ensure favorable living conditions and environmental improvement of the territory, justification of measures to improve the process of anthropogenic and man-made loads frame elements in the regions and appropriate regulation of economic activity [13, p. 229]".

Determining and mapping the framework of anthropogenic and man-made loads in the study region is of great scientific and applied importance. It allows you to compare the natural and anthropogenic-technogenic frameworks of the region, to identify the most problematic areas. In the future, on the basis of an integrated map, we have the opportunity to develop measures to reduce the harmful effects of anthropogenictechnogenic load, to justify in the process of geoplanning strategy of rational territorial organization of naturepopulation-economy in order to achieve environmental safety and improve the quality of life.

Mandatory basis for the formation of eco-networks is land management. The main methodological problem: the categories of land that are part of the regional ecological network do not correspond (do not agree) to the structure of land, which is used by modern land accounting:

-not taken into account the land of the water fund (land design is required)

- non-certified (mostly) recreational and resort lands;

- disorderly accounting of degraded and unproductive agricultural lands, etc.

Experts are faced with the question - at the expense of which lands can be formed eco-networks? There are already the first concepts and programs for the formation of regional eco-networks (Odesa region, etc.), in which the share of eco-networks in the total area of the regions reaches $25-30 \%$ [6]. There are categories of lands that will be fully part of ecological networks. These are territories and objects of the nature reserve fund, forest lands, and recreational territories. But there are few such lands in most regions of the country. The main reserve for the formation of ecological networks should be the lands of the water fund. Currently, five categories of water fund lands are legally defined, and nature use regulations have been established for them.

In accordance with Part 1 of Art. 58 of the Land Code of Ukraine, the lands of the water fund include lands occupied by:

a) seas, rivers, lakes, reservoirs, other bodies of water, swamps and islands not occupied by forests;

b) coastal protection strips along seas, rivers and around reservoirs, except for lands occupied by forests (rivers less than 3 ha $-25 \mathrm{~m}$; rivers and reservoirs more than $3 \mathrm{ha}-50 \mathrm{~m}$; for large rivers and lakes $-100 \mathrm{~m}$; along the sea, sea bays and estuaries not less than $2 \mathrm{~km}$ );

c) hydraulic, other water management structures and canals, as well as lands allocated for allotment strips for them; (they are designed primarily to protect facilities from pollution, littering, depletion and certain economic activities related to the use of water bodies. The peculiarity of these lands is that a special regime of use is established for them);

d) coastal strips of waterways;

e) artificially created land plots within the waters of seaports.

But these categories of land are not allocated on the ground and, therefore, have no real restrictions on economic use. Allocation of water fund lands in kind and strict regulation of their use is the main prerequisite for the formation of ecological networks of Ukraine and its regions.

Within the Odesa region, water fund lands occupy 210.73 thousand hectares or $6.3 \%$ of the region's territory, including natural rivers and streams - 15.3 thousand hectares, lakes and estuaries - 167.2 thousand hectares, ponds - 12.1 thousand hectares, artificial reservoirs - 7.6 thousand hectares, artificial drains (canals, collectors, ditches) - 8.4 thousand hectares. Open wetlands - these are mostly tidal or estuarine areas, occupying 72.5 thousand hectares. All these lands are suitable for the development of the ecological network.

As for other categories of water fund lands (coastal protection strips, etc.), at present their allocation on the ground has only just begun. Thus, water protection zones occupy 183.3 thousand hectares on 01.01.2020, coastal protection strips -35.17 thousand hectares [13].

Due to its coastal location, the region has large areas of recreational and resort lands that could potentially be part of the eco-network. To date, the development of land design documentation for these areas is underway, and although compared to 2014 their area has increased slightly - from 2.7 thousand hectares on 01.01 .2014 to 3.1 thousand hectares at the beginning of 2020. But even the last figure is a very small share in the structure of the regional potential of the eco-network. 
A significant reserve for the formation of a regional ecological network are unproductive and degraded agricultural lands, which have lost their agricultural potential due to intensive and irrational use. These are eroded, swampy, wet, saline, contaminated with heavy metals, rocky, acidic agricultural lands. The ecological network, in particular its natural corridors and buffer zones, may also include agricultural lands of extensive use - extensive use - hayfields, which and pastures, which occupy 401.7 thousand hectares or $12.1 \%$ of the entire region.

The total area of degraded agricultural land in the region, which must be included in the ecological network, is 1242.3 thousand hectares. In the near future it is necessary to withdraw these unproductive lands from agricultural use and transfer them to the composition of natural lands - forests, shrubs, meadows, steppes.

When comparing the developed scheme of the regional ecological network [13] with the landscape map [14], it can be noted that the following landscapes are most covered by the ecological network in the Odesa region: floodplain forest, meadow-swamp, meadow steppe floodplains, floodplains, which are located in the valleys of the Danube, Dniester and their tributaries; they are the meridional ecological corridors of the national and regional level. Also, in the ecological network of the region are widely represented dry-steppe terraced and ancient delta hilly sandy landscapes with slightly humus-rich soils under the forests - the lower reaches of the Danube and Dniester rivers. The northeastern part of the region, which is located in the ForestSteppe zone of the South Podilliy Upland region, is also distinguished by its high share of territories that can be included in the ecological network. It is characterized by forest-steppe upland undulating forest landscapes with gray forest and dark gray podzolic soils, with hornbeam oaks and forest-steppe upland eroded landscapes with deep chernozems, hornbeam and oaks forests, ravines. It is through this territory the Galichansko-Slobozhansky latitudinal ecological corridor of the national level passes. Forest-steppe ecosystems are represented by a large number of nature reserve fund objects of both national and local significance.

Despite the fact that most of the region belongs to the Steppe zone, within which the Northern and Middle Steppe subzones are represented, the steppe landscapes of the subzones are insufficiently reflected in the regional ecological network due to extreme variability and fragmentation. To date, there is no scheme of the South Ukrainian latitudinal eco-corridor, which runs within the North Steppe subzone, only its natural cores (Kuchurgan-Andriyashivske and Kuyalnytske) are presented, which are quite difficult to unite with connecting corridors due to plowed lands. That is, steppe ecosystems in the middle part of the region, with the exception of protected areas, have been so altered by agricultural activities that at present it is not even possible to consider them as potentially suitable for the creation of an ecological network. Further more detailed design of the regional eco-network requires additional surveys and analysis of land use, in order to cover the eco-network of all subtypes of landscapes in the region.

\section{Conclusions}

Thereby the development of the ecological network as a mandatory element of the rational territorial organization of society allows to some extent to eliminate the imbalances between economic development and environmentally friendly nature management. Legislative definition of the basic theoretical, methodological, methodical questions of formation of ecological networks of various levels allows developing reasonably regional programs and schemes of formation of an ecological network, and such work is already actively carried out. It is clear that at the regional level at the initial stage of such research it is necessary to make some inventory of spatial resources that could potentially be used to build an eco-network. Execution of such tasks in the context of complex planning of territories of regions is an important direction of activity of modern social geographers.

So, the features of creation of the regional ecological network of Odesa region are caused by its coastal position. In coastal areas, there is a growing contradiction between the attractiveness for settlement and the main economic activities, on the one hand, and the exceptionally high environmental vulnerability of sea coasts and adjacent waters - on the other. The natural framework of ecological safety of Odesa region includes elements of the ecological network of different levels international, national, regional and local. The main reserve for the formation of the regional ecological network of Odessa region is water fund lands, degraded and unproductive agricultural lands. Allocation of water fund lands in kind and their mapping on land use plans requires appropriate funding and design. Regional ecological networks must be coordinated with each other within a single national ecological network, as well as with micro-elements of the Trans-European Ecological Network. Therefore, it is important to develop crossborder coordination and connection of elements of ecological networks of neighboring regions and neighboring countries.

\section{References}

1. V.Oleshchenko, Ya. Movchan, H. Parchuk, Normatyvno-pravovi pidstavy dlia rozbudovy ekomerezhi Ukrainy (Regulatory and legal grounds for the development of the ecological network of Ukraine). (Kyiv, 1999)

2. Formuvannia rehionalnykh skhem ekomerezhi (metodychni rekomendatsii) (Formation of regional schemes of an ecological network (methodical recommendations)) ed by Ju.R.Sheljah-Sosonko. (Fitosociocentr, Kyiv, 2004)

3. O.H. Topchiiev, L.P. Platonova, A.M. Shashero, Kontseptsiia karkasiv ekolohichnoi bezpeky krain $i$ rehioniv yak suchasna paradyhma heohrafii (The 
concept of ecological security frameworks of countries and regions as a modern paradigm of geography). (Akademperyodyka, Kyiv, 2006)

4. O.V. Kohan, Ya.I. Movchan, L.D. Protsenko, V.A. Kostiushyn, V.D. Siokhin, Ekomerezha AzovoChornomorskoho pryrodnoho korydoru (Econetwork of the Azov-Black Sea natural corridor). (Khimdzhest, Kyiv, 2012)

5. Ekomerezha stepovoi zony Ukrainy: pryntsypy stvorennia, struktura, elementy (Eco-network of the steppe zone of Ukraine: principles of creation, structure, elements) ed by D.V. Dubina, Ya.I. Movchan. (LAT\&K, Kyiv, 2013)

6. V.A. Sych, V.V. Yavorska, K.V. Kolomiyets, Features of the formation of the ecological network of the Ukrainian Black Sea region. Odesa National University Herald, Series Geography\&Geology, 20, 4 (2015)

7. V.I. Karamushka, Prostorove planuvannia rozvytku pryberezhnoi smuhy moriv Ukrainy (Spatial planning of the development of the coastal strip of the seas of Ukraine). (Print Bistro, Odesa, 2009)

8. Department of Ecology and Natural Resources of the Odessa Regional State Administration, https://oda.odessa.gov.ua. Accessed at 14 Jan. 2021

9. Zakon Ukrajiny "Pro Heneralnu sxemu planuvannja terytoriji Ukrajiny" (Law of Ukraine "On the
General Scheme of Territorial Planning of Ukraine"). (Kyiv, 2002)

10. O.H. Topchiiev, Suspilno-heohrafichni doslidzhennia: metodolohiia, metody, metodyky (navchalnyi posibnyk) Socio-geographical research: methodology, methods, techniques (textbook) (Astroprint, Odesa, 2005)

11. V.A. Sych, A.M. Shashero, K.V. Kolomiyets, Framework of anthropogenic and technogenic loads on the territory of the Ukrainian Black Sea region. Odesa National University Herald, Series Geography\&Geology, 24, 1 (2019)

12. O.H. Topchiiev, D.S. Malchikova, I.O. Pylypenko, V.V. Yavorska, Metodolohichni osnovy heohrafii: Landshaftna obolonka Zemli. Dovkillia: navch. posib.(Methodological bases of geography: Landscape of the Earth. Environment: textbook. (Helvetyka, Kherson, 229, 2018)

13. Rehionalna dopovid pro stan navkolyshnoho pryrodnoho seredovyshcha v Odeskii oblasti u 2019 rotsi (Regional report on the state of the environment in Odessa region in 2019). (ODA, Odesa, 2020)

14. Natsional'nyy atlas Ukrayiny, (National Atlas of Ukraine) ed. by L.H. Rudenko. (DNVP Kartohrafiya, Kyiv, 2007) 